\title{
The Modulation of Oxytocin and Cortisol Levels in Major Depression Disorder and Irritable Bowel Syndrome
}

\author{
LUMINITA HRITCU1, ILIE OVIDIU DUMITRU ${ }^{2}$, MANUELA PADURARIU ${ }^{3}$, ALIN CIOBICA ${ }^{2,4,5}$, \\ MIHAELA CLAUDIA SPATARU ${ }^{1}$, CONSTANTIN SPATARU ${ }^{1 *}$, GABRIELA STEFANESCU ${ }^{3 *}$, \\ CRISTINEL STEFANESCU ${ }^{3 *}$, CRISTIAN GRECU-GABOS ${ }^{6}$ \\ ${ }^{1}$ Ion Ionescu de la Brad University of Agricultural Science and Veterinary Medicine, 3 Sadoveanu Alley, 700490 Iasi, \\ Romania \\ ${ }^{2}$ Alexandru Ioan Cuza University, Department of Research, Faculty of Biology, 11 Carol I Blvd.,700506, Iasi, Romania \\ ${ }^{3}$ Grigore T.Popa University of Medicine and Pharmacy, 16 Universitatii Str., 700115, Iasi, Romania \\ ${ }^{4}$ Academy of Romanian Scientists, 54 Splaiul Independentei Str., 050094, Bucuresti, Romania \\ ${ }^{5}$ Center of Biomedical Research, Romanian Academy, 8 Carol I Blvd., 700506, Iasi, Romania \\ ${ }^{6}$ University of Medicine and Pharmacy, Departament of Psychiatry, 38 Gheorghe Marinescu Str., 540139, Targu Mures \\ Romania
}

There is a progressive trend in the current literature in understanding the central effects of oxytocin, which besides its classical roles in parturition and lactation, seems to exert some facilitatory effects in most of the neuropsychiatric disorders. Thus, it seems that oxytocin is mainly linked to the neuropsychiatric disorders where the social component is more or less affected and it has also strong correlations with the stress-related mechanisms and hypothalamic-pituitary-adrenal (HPA) axis. In addition, the connections between oxytocin and the digestive system were previously suggested, including by some of our preliminary results, in the context of irritable bowel syndrome (IBS) pathology. Also, the relations between depression and stress in the context of cortisol implications are quite well described, although various modifications of cortisol (increased, decreased or nonmodified) were described in the major depression pathology. Thus, by using two research cohorts: one with major depression disorder $(n=15)$ and another one having both diagnosis of major depression disorder and irritable bowel syndrome in the same time $(n=15)$, we are showing in this report significantly increased levels of cortisol in patients with MDD and IBS, when compared with patients with MDD without IBS, while an opposite pattern was obtained by measuring the plasma level of oxytocin, where the patients with MDD and IBS had a significantly decreased concentration of oxytocin, as compared with those with MDD but without IBS.

Keywords: oxytocin, cortisol, depression, irritable bowel syndrome.

As described several times by our group already, there is a progressive trend in the current literature in understanding the central effects of oxytocin, which besides its classical roles in parturition and lactation, seems to exert some facilitatory effects in most of the neuropsychiatric disorders [1-7].

Thus, it seems that oxytocin is mainly linked to the neuropsychiatric disorders where the social component is more or less affected and it has also strong correlations with the stress-related mechanisms and hypothalamic-pituitary-adrenal (HPA) axis [1], as we will further discuss.

In addition, the connections between oxytocin and the digestive system were previously suggested, including by some of our preliminary results (in the context of irritable bowel syndrome (IBS) pathology [8].

Also, the relations between depression and stress in the context of cortisol implications are quite well described, although various modifications of cortisol (increased, decreased or non-modified) were described in the major depression pathology [9-18].

In this context, in this mini-report we will focus our attention especially on the possible correlations that might exist between oxytocin, cortisol and the HPA axis, in the previously described context of the major depressive disorder, but also considering the gastrointestinal aspects mentioned above, by introducing here the previously described $[8,19]$ IBS pathology. This was done by determining oxytocin and cortisol modulatory variations in two research cohorts: one with major depression disorder and another one having both diagnosis of major depression disorder and irritable bowel syndrome in the same time $[8,19]$.

*email:cspatarufmv@yahoo.com,gabriela.stefanescu@umfiasi.ro,cristinel.stefanescu@gmail.com 


\section{Experimental part}

Material and methods

Patients with the diagnosis of depression and IBS from Iasi Institute of Psychiatry were selected. The local specialized committee approved the present design, while the patients also signed a specific informed approval to be part of this study. Exclusion criteria were represented by other psychiatric, digestive or somatic diseases. ICD-10 and DSM V criteria for used for the diagnosis of major depression disorders (MDD), while ROME IV criteria were used for IBS diagnosis. HAMD scale was applied on all 30 slected patients. Also the patients were grouped into two research cohorts: one with major depression disorder $(\mathrm{n}=15)$ and another one having both diagnosis of major depression disorder and irritable bowel syndrome in the same time $(\mathrm{n}=15)$. Blood samples were collected from all of them in order to determine the oxytocin and cortisol concentrations, which were performed as previously described [8, 19]. Data analysis was also done as previolsy described by our group $[8,19]$.

\section{Results and discussions}

The average age was between 20 to 60 years of age, with both male and female coming from urban and rural background.

As it can be seen in figure 1 , cortisol level $(\mathrm{ng} / \mathrm{ml})$ was significantly increased $(\mathrm{p}<0.05)$ in patients with MDD and IBS, when compared with patients with MDD without IBS (Fig. 1).

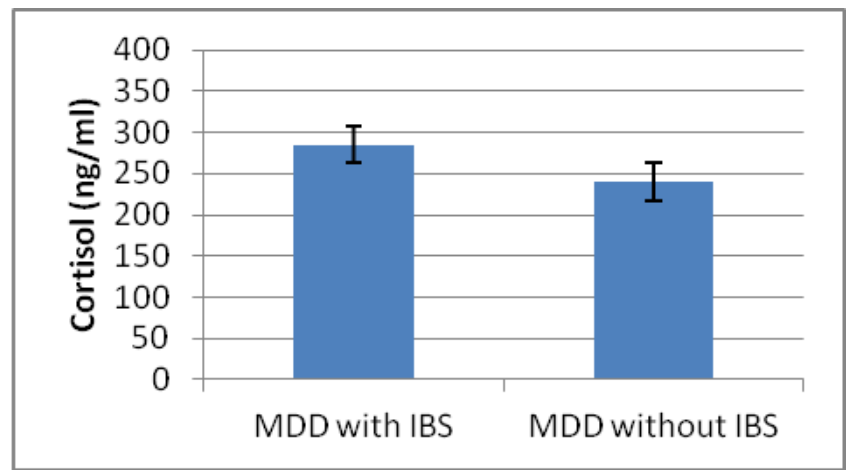

Fig. 1. Cortisol level (ng/ml) in patients having either major depression disorder $(n=15)$ or having both diagnosis of major depression disorder and irritable bowel syndrome in the same time $(n=15)$

An opposite pattern was obtained in the second case by measuring the plasma level of oxytocin (pg/mL), where the patients with MDD and IBS had a significantly decreased $(\mathrm{p}<0.05)$ concentration of oxytocin, as compared with those with MDD but without IBS (Fig. 2).

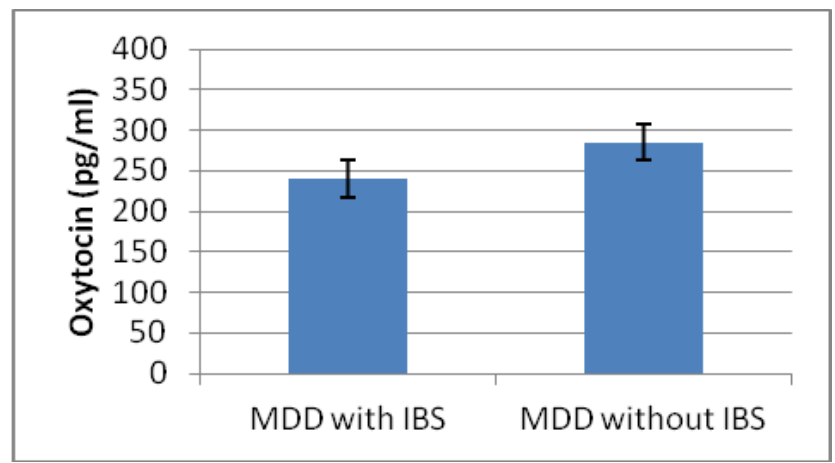

Fig. 2. Comparison of Oxytocin level in patients with MDD accompanied by IBS compared with those with only MDD without IBS $(p=0.024,<0.05)$

Another issue we wanted to examine was whether age influences the oxytocin-cortisol connection in patients with MDD and IBS (Fig. 3), but also for each sex.

Although there is a tendency for a correlation between cortisol + oxytocin levels in male subjects with MDD and IBS, this is not statistically significant $(r=0,415, p>0,05)$ (Fig. 4). In female subjects however, the results were more 
conclusive for those two measured parameters $(\mathrm{r}=0.81)$. In this case, two distinct situations are encountered: when cortisol levels are low, it is counterbalanced with that of oxytocin and vice versa, with the correlations being highly significant statistically $(0=0.007 ;<0.05)$ (Fig. 5).
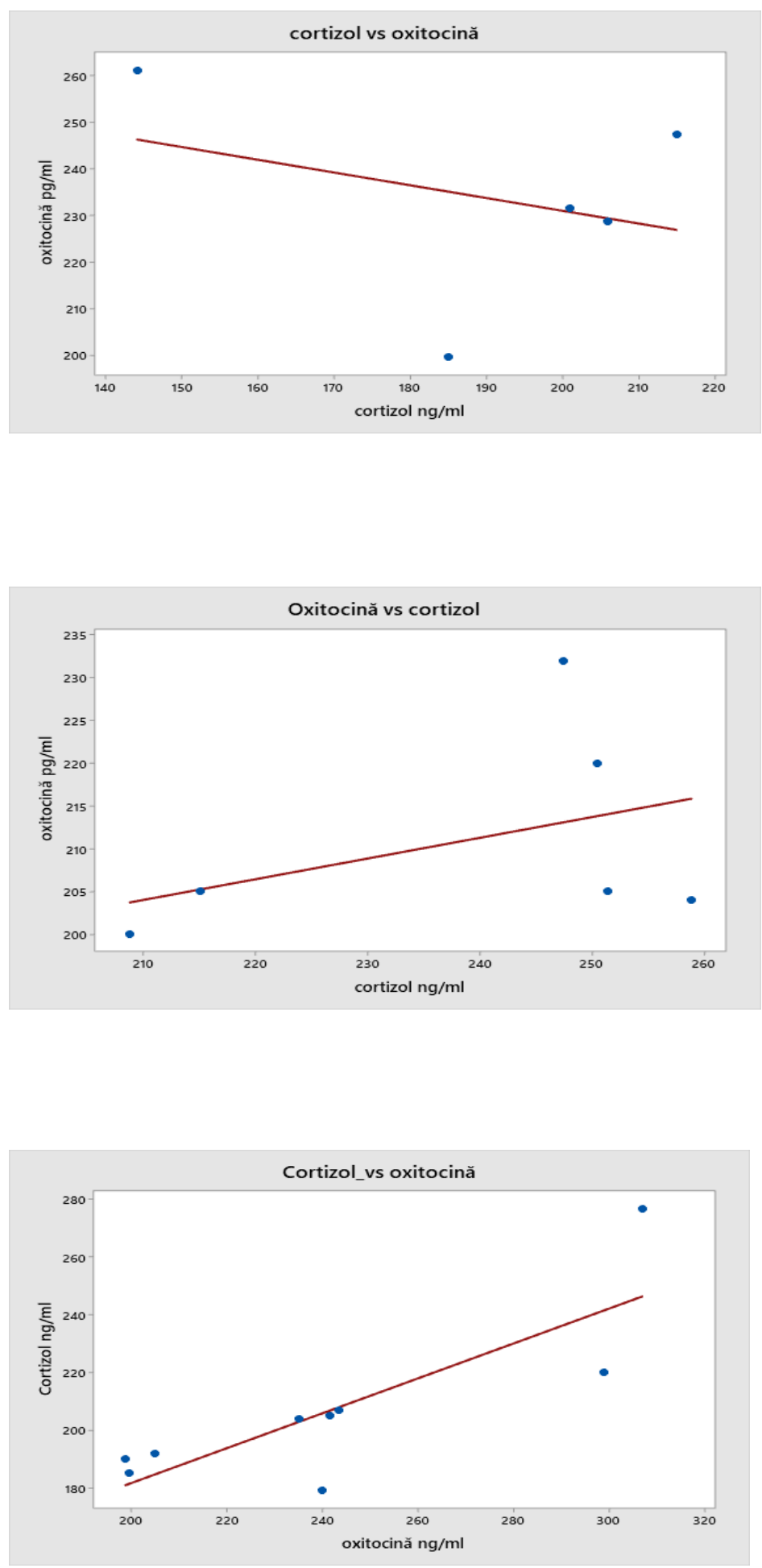

Fig. 3. Pearson correlations between cortisol and oxytocin by age group for patients with MDD and IBS $(r=-0.33, p>0.58)$

Fig. 4. Pearson correlations between cortisol $(\mathrm{pg} / \mathrm{mL})$ and oxytocin $(\mathrm{ng} / \mathrm{mL})$ for the male population with MDD and IBS $(r=0.415, p>0.05)$

To test the hypothesis that oxytocin influences the level of cortisol in MDD accompanied by IBS, we also tested for possible relationship between these two parameters and used Pearson correlation. The data indicated a highly statistically positive link $(\mathrm{r}=0,66 ; \mathrm{p}=0,02)$. Thus, we can say with certainty that there is a directly proportional decrease in concentration of these hormones (Fig. 6). 


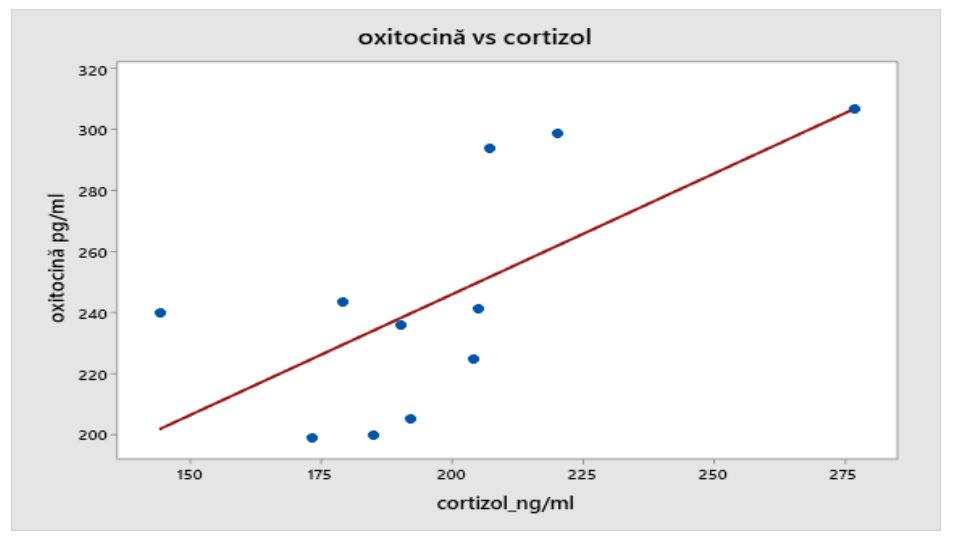

Fig. 6. Pearson correlations between

oxytocin $(\mathrm{pg} / \mathrm{mL})$ and cortisol $(\mathrm{ng} / \mathrm{mL})$ concentrations

$(\mathrm{r}=0.66 ; \mathrm{p}=0.02)$ in patients with

MDD and IBS

In the present study, by using two research cohorts: one with major depression disorder and another one having both diagnosis of major depression disorder and irritable bowel syndrome, we showed significantly increased levels of cortisol in patients with MDD and IBS, when compared with patients with MDD without IBS, while an opposite pattern was obtained by measuring the plasma level of oxytocin, where the patients with MDD and IBS had a significantly decreased concentration of oxytocin, as compared with those with MDD but without IBS.

Considering that we previously described in an extensive way the connections between oxytocin and the gastrointestinal system (for further details please see [8], in the present section we will focus on the modulatory effects of oxytocin-cortisol interactions.

It is also known that oxytocin actions are very dependent on the environmental context and are in dynamic relations with many other systems and neurotransmitters or hormones, including cortisol $[1,4,20]$.

Thus, it was previously showed also by our research group that oxytocin could act indeed as some anti-stress agent, modulating, among others, cortisol levels and HPA axis in most of the stressful situations [1, 19]. However, these interactions are also very complex and controversial, with previous reports describing contradicting results. For example, in a classical study by Cardoso et al., it was showed that intranasal oxytocin administration would result in a decrease of salivary cortisol levels [21], while other groups showed that exposure to specific social stress in postmenopausal women will generate increased levels of both oxytocin and cortisol [22].

These effects could be related to various imbalances, modulatory effects and long term disruptions in the activity of these two hormones. Also we should mention that cortisol and HPA axis are only part of the complex responses to stress exposure and their further effect on oxytocin modulation. Additionally, oxytocin interacts with a variety of other neurotransmitters and hormones (e.g. related to depressive-like states) [1].

Thus, we set ourselves to see to what extent the indices for oxytocin and cortisol oscillate in subjects diagnosed with MDD alongside IBS which plays the role of amplifier. By the prism of the cohort used in both cases, it can be concluded that these hormones acts complementary.

Cortisol could modulate the amount of oxytocin in the feedback to HPA, through the activation of arginine vasopressin (AVP), responsible for variations of cortisol degree $[23,24]$.

Modifications of cortisol as an output of HPA axis, has affinity towards comorbidities [25], an hyperactivity of HPA being related to cognitive impairment [26], withdrawn attitude [27] and mood changes [28]. This highlights a possible relevance of oxytocin in this context, because it has been postulated that plasma oxytocin levels are directly correlated with the actions of the HPA axis retroactively [29].

Apart from the design of our study, could be encountered states like panic or social anxiety disorders, Camilleri [30] suggesting that anxiety could be a precursor to the early stages of IBS, whereas in depressants, the process is chronic and more common. For example, chronic stress induce an hyperreactivity of suprachiasmatic and paraventricular nuclei [31, 32], evidences supported furthermore by studies that focused on fetal hypoxia [33].

Petacchioli et al [34] contradicts the results obtained by Cardoso et al [21] where he recorded an elevating degree of cortisol in the saliva of 55 IBS patients compared with controls, data that is not sustained by eventual modifications of profiles. Another example is represented by the study conducted by Sugaya et al [35] where 10 female college student were expose to two weeks stressful teaching kindergarten practice. After 7 days, saliva samples indicate an increased amount of cortisol as opposed to other four experimental situations: thirtieth minutes post-awakening or before sleep, during practicing and few days later.

Heinrichs et al [36] for example tested 37 male subjects who were exposed to social stress and then received clinical assistance by the administration of intranasal oxytocin or placebo prior to Trier Social Stress Test (TSST). The variations were less pronounced compared to patients who underwent only social care, oxytocin or none. In a similar manner were 
evaluated children, where those who could hear or see their mothers displayed higher amounts of OT and lower of cortisol, data being antithetical to those who did not [37].

Compared with irritable bowel disease (IBD) who is more like an organic disease, IBS lies more in the spectrum of functionality, gastrointestinal deficiency who has been associated with neuropsychiatric disturbances [38-40], due to prolonged exposure to stressful stimuli $[34,35]$.

As Ohlsson et al [41] showed that oxytocin is as well distributed throughout gastrointestinal (GI) tract via Auerbach's and Meissner's plexus and nerve fibres, recent findings support his role in gastric modulations in diabetes or gastroparesis [42], colonic peristaltism [43], intranasal administration alleviating discomfort associated with chronic idiopathic constipation [44].

Intestinal epithelium ensure favorable conditions for pathogens who initiate inflammatory cascades (IL6 and IL8 in all IBS subtypes), secretion of neuro- and endotoxins, deficient absorption of nutrients and modulation of autonomic nervous system [30]. However, once a rupture of the tight junctions occurs, commensal bacteria prevents the adherence of harmful microorganisms by promoting the activation of immune system, while Paneth cells usually confer protection on intestinal epithelium $[45,46]$.

Therapies targeting human microbiota could constitute a reliable branch of expertise in order to deepen the understanding of how a dysbiosis promote various deregulations such as an increased gut permeability [30].

\section{Conclusions}

Thus, by using two research cohorts (e. g. one with major depression disorder and another one having both diagnosis of major depression disorder and irritable bowel syndrome), we are showing in this paper significantly increased levels of cortisol in patients with MDD and IBS, when compared with patients with MDD without IBS, while an opposite pattern was obtained by measuring the plasma level of oxytocin, where the patients with MDD and IBS had a significantly decreased concentration of oxytocin, as compared with those with MDD but without IBS. Our results strongly demonstrate the interdependence between oxytocin and cortisol in regulating depression, in the context of IBS pathology (e.g. associated or not). Thus, it is possible that disruption of the HPA axis promotes gastrointestinal deficiencies such as irritable bowel syndrome, mainly depending on the exogenous factors. On a longer term, based on large-scale distribution in the body of OT, especially in the gut, therapies targeting the gut microbiota could be a new starting point of a major therapeutic approach, by the manipulation of the „second brain” represented by the gastrointestinal tract.

Acknowledgements: PM and AC are supported by a research TE grant offered by UEFISCDI Romania, no. PN-III-P1-1.1-TE-2016-1210, contract no. 58 from 02/05/2018, called "Complex study regarding the interactions between oxidative stress, inflammation and neurological manifestations in the pathophysiology of irritable bowel syndrome (animal models and human patients)."

\section{References}

1. CIOBICA, A., BALMUS, I.M., PADURARIU, M., Acta Endocrinologica, 12, no. 1, 2016, p. 65, doi: 10.4183/aeb.2017.60.

2. PADURARIU, M., PREPELITA, R., CIOBICA, A., DOBRIN, R., TIMOFTE, D., STEFANESCU, C., CHIRITA, R., Neurophysiology, 48, no. 4, 2016, p. 312 doi: 10.1016/j.yhbeh.2017.06.001.

3. PADURARIU, M., CIOBICA, A., Nobel Medicus, 13, no. 3, 2017, p. 5.

4. VARGÁNÉ, K.A., CIOBICA, A., TOPAL, J., Horm Behav, 28, no. 94, 2017, p. 40. doi: 10.1016/j.yhbeh.2017.06.001

5. ANTIOCH, I., ABABEI, D., LEFTER, R., CIOBICA, A., HONCERIU, C., BILD, V., Rev. Chim. (Bucharest), 68, no. 9, 2017 , p. 2028.

6. BALMUS, I.M., LEFTER, R., CIOBICA, A., ANTIOCH, I., ABABEI, D., DOBRIN, R., Psychiatr Danub, 30, no. 1, 2018, p. 9, doi: 10.24869/ psyd.2018.91.

7. PADURARIU, M., BALMUS, M., CIOBICA, A., LEFTER, R., COJOCARU, S., ANTIOCH, I., FOYET, H., DOBRIN, R., ABABEI, D., BILD, V., Farmacia, 66, no. 3, 2018, p. 421.

8. GAVRIL, R., hritcu, L., PADURARIU, M., CIOBICA, A., HORHOGEA, C., STEFANESCU, G., SPATARU C.M., STRAUlEA. C., STEFANESCU. C., Rev. Chim. (Bucharest), 70, no. 6, 2019, p. 2204.

9. VREEBURG, S.A., HOOGENDIJK, W.J., DERIJK, R.H., VAN DYCK, R., SMIT, J.H., ZITMAN, F.G., PENNINX, B.W., Psychoneuroendocrinology, 38, no. 9, 2013, p. 1494, https://doi.org/10.1016/j.psyneuen.2012.12.017.

10. HOLSBOER, F., Neuropsychopharmacology, 23, 2000, p. 477, doi:10.1016/S0893-133X(00)00159-7.

11. PLOTSKY, P.M., OWENS, M.J., NEMEROFF, C.B., Psychiatr Clin North Am, 21, 1998, p. 293, DOI: 10.1016/s0193-953x(05)70006-x.

12. DIENES, K.A, HAZEL, N.A., HAMMEN, C.L., Psychoneuroendocrinology, 38, no. 6, 2013, p. 927, doi: 10.1016/j.psyneuen.2012.09.019

13. VREEBURG, S.A., HOOGENDIJK, W.J., VAN PELT, J., DERIJK, R.H., VERHAGEN, J.C., VAN DYCK, R., SMIT, J.H., ZITMAN, F.G., PENNINX, B.W., Arch. Gen. Psychiatry, 66, no. 6, 2009, p. 617, doi:10.1001/ archgenpsychiatry.2009.50. 14. CARROLL, B.J., CASSIDY, F., NAFTOLOWITZ, D., TATHAM, N.E., WILSON, W.H., IRANMANESH, A., LIU, P.Y., VELDHUIS, J.D., Acta Psychiatr. Scand., 115, 2007, p. 90, doi:10.1111/j.1600-0447.2007.00967.x.

15. MAES, M., CALABRESE, J., MELTZER, H.Y., Prog. Neuropsychopharmacol. Biol. Psychiatry, 18, no. 3, 1994, p. 503, doi: 10.1016/02785846(94)90008-6.

16. PEETERS, F., NICOLSON, N.A., BERKHOF, J., Psychiatry Res., 126, no. 1 2004, p. 1, doi:10.1016/j.psychres.2003.12.010.

17. STRICKLAND, P.L., DEAKIN, J.F.W., PERCIVAL, C., DIXON, J., GATER, R.A., GOLDBERG, D.P., Br. J. Psychiatry, 180, 2002, p. 168, doi:10.1192/bjp.180.2.168. 
18. BHAGWAGAR, Z., HAFIZI, S., COWEN, P.J., Psychopharmacology (Berl), 182, no. 1, 2005, p. 54, doi:10.1007/s00213-005-0062-z.

19. HRITCU, D.L., PADURARIU, M., CIOBICA, A., HORHOGEA, C., SPATARU, C.M., SPATARU, C., BURTAN, L., STEFANESCU, C., Rev. Chim. (Bucharest), 70, no. 6, 2019, p. 3383.

20. HERNÁDI, A., KIS, A., KANIZSÁR, O., TÓTH, K., MIKLÓSI, B., TOPÁL, J., Behav Processes, 119, 2015, p. 1, doi: 10.1016/j.beproc.2015.07.001.

21. CARDOSO, C., ELLENBOGEN, M.A., ORLANDO, M.A., BACON, S.L., JOOBER, R., Psychoneuroendocrinology, 38, no. 3, 2013, p. 399, doi: 10.1016/j.psyneuen.2012.07.013.

22. TAYLOR, S.E., GONZAGA, G.C., KLEIN, L.C., HU, P., GREENDALE, G.A., SEEMAN, T.E., Psychosom Med, 68, no. 2, 2006, p. 238, doi: 10.1097/01.psy.0000203242.95990.74.

23. DE WINTER, R.F., VAN HEMERT, A.M., DERIJK, R.H., ZWINDERMAN, K.H., FRANKHUIJZEN-SIEREVOGEL, A.C., WIEGANT, V.M., GOEKOOP, J.G., Neuropsychopharmacology, 28, no. 1, 2003, p. 140, doi: 10.1038/sj.npp.1300002.

24. BARIBEAU, D.A., ANAGNOSTOU, E., Front Neurosci, 9, 2015, 335, doi: 10.3389/fnins.2015.00335.

25. DEKEL, S., EIN-DOR, T., ROSEN, J.B., BONANNO, G.A., Front Psychol, 8, 2017, 797, doi: 10.3389/fpsyg.2017.00797.

26. IOB, E., KIRSCHBAUM, C., STEPTOE, A., Mol Psychiatry, [Epub ahead of print], doi: 10.1038/s41380-019-0501-6.

27. TOPS, M., WIJERS, A.A., VAN STAVEREN, A.S., BRUIN, K.J., DEN BOER, J.A., MEIJMAN, T.F., KORF, J., Biol Psychol, 69, no. 2, 2005, p. 181, doi: 10.1016/j.biopsycho.2004.07.005.

28. JOKINEN, J., NORDSTRÖM, P., J Affect Disord, 116, no. 1-2, 2009, p. 117, doi: 10.1016/j.jad.2008.10.015.

29. SCANTAMBURLO, G., HANSENNE, M., FUCHS, S., PITCHOT, W., MARÉCHAL, P., PEQUEUX, C., ANSSEAU, M., LEGROS, J.J., Psychoneuroendocrinology, 32, no. 4, 2007, p. 407, doi: 10.1016/j.psyneuen.2007.01.009.

30. CAMILLERI, M., Gastroenterology, 120, no. 3, 2001, p. 652, doi: 10.1053/gast.2001.21908.

31. HERMAN, J.P., FLAK, J., JANKORD, R., Prog Brain Res, 170, 2008, p. 353, doi: 10.1016/S0079-6123(08)00429-9.

32. FLAK, J.N., OSTRANDER, M.M., TASKER, J.G., HERMAN, J.P., J Comp Neurol, 517, no. 2, 2009, p. 156, doi: 10.1002/cne.22142.

33. TYZIO, R., COSSART, R., KHALILOV, I., MINLEBAEV, M., HÜBNER, C.A., REPRESA, A., BEN-ARI, Y., KHAZIPOV, R., Science, 314, no. 5806, 2006, p. 1788, doi: 10.1126/science.1133212.

34. PATACCHIOLI, F.R., ANGElUCCI, L., DELlERBA, G., MONNAZZI, P., LERI, O., J Endocrinol Invest, 24, no. 3, 2001, p. 173, doi: $10.1007 / \mathrm{bf} 03343838$

35. SUGAYA, N., IZAWA, S., SAITO, K., SHIROTSUKI, K., NOMURA, S., SHIMADA, H., Biopsychosoc Med, 9, no. 1, 2015, 4, doi: 10.1186/s13030-015-0031-7.

36. HEINRICHS, M., BAUMGARTNER, T., KIRSCHBAUM, C., EHLERT, U., Biol Psychiatry, 54, no. 12, 2003, p. 1389, doi: 10.1016/s00063223(03)00465-7.

37. THOMPSON, L.A., TREVATHAN, W.R., J Reprod Infant Psychol, 27, no. 2, 2009, p. 143, doi: 10.1080/02646830801918463.

38. LEFTER, R., CIOBICA, A., GUENNÉ, S., COMPAORÉ, M., KIENDREBÉOGO, M., STANCIU, C., TRIFAN, A., Neurophysiology, 50, no. 4, 2018, p. 266, doi:10.1007/s11062-018-9748-9.

39. LEFTER, R., CIOBICA, A., TIMOFTE, D., ABABEI, D., DOBRIN, R., LUCA, A., TRIFAN, A., STANCIU, C., SFARTI, C., Rom Biotechnol Lett, [Epub ahead of print], doi: 10.26327/RBL2018.208.

40. COJOCARIU, R., CIOBICA, A., BALMUS, I.M., GUENNÉ, S., TRIFAN, A., STANCIU, C., HRITCU, L., LEFTER, R., Oxid Med Cell Longev, 2019, 3492767, doi: 10.1155/2019/3492767.

41. OHLSSON, B., TRUEDSSON, M., DJERF, P., SUNDLER, F., Regul Pept, 135, no. 1-2, 2006, p. 7, doi: 10.1016/j.regpep.2006.03.008.

42. BORG, J., OHLSSON, B., BMC Res Notes, 5, 2012, 148, doi: 10.1186/1756-0500-5-148.

43. OHLSSON, B., RINGSTRÖM, G., ABRAHAMSSON, H., SIMRÉN, M., BJÖRNSSON, E.S., Neurogastroenterol Motil, 16, no. 2, 2004, p. 233, doi: 10.1111/j.1365-2982.2004.00507.x.

44. LOUVEL, D., DELVAUX, M., FELEZ, A., FIORAMONTI, J., BUENO, L., LAZORTHES, Y., FREXINOS, J., Gut, 39, no. 5, 1996, p. 741, doi: 10.1136/gut.39.5.741.

45. CHOW, J., LEE, S.M., SHEN, Y., KHOSRAVI, A., MAZMANIAN, S.K., Adv Immunol, 107, 2010, p. 243, doi: 10.1016/B978-0-12-3813008.00008-3.

46. VAISHNAVA, S., BEHRENDT, C.L., ISMAIL, A.S., ECKMANN, L., HOOPER, L.V., Proc Natl Acad Sci U S A, 105, no. 52, 2008, p. 20858, doi: 10.1073/pnas.0808723105.

Manuscript received: 20.12 .2019 